This item was submitted to Loughborough's Research Repository by the author.

Items in Figshare are protected by copyright, with all rights reserved, unless otherwise indicated.

\title{
Restoration of keratocyte cell phenotype through epithelial-stromal cell interactions in a 3D hydrogel model [abstract]
}

\section{PLEASE CITE THE PUBLISHED VERSION}

https://doi.org/10.1111/j.1755-3768.2013.2471.x

\section{PUBLISHER}

John Wiley \& Sons (@ Acta Ophthalmologica Scandinavica Foundation)

\section{VERSION}

AM (Accepted Manuscript)

\section{PUBLISHER STATEMENT}

This work is made available according to the conditions of the Creative Commons Attribution-NonCommercialNoDerivatives 4.0 International (CC BY-NC-ND 4.0) licence. Full details of this licence are available at: https://creativecommons.org/licenses/by-nc-nd/4.0/

\section{LICENCE}

CC BY-NC-ND 4.0

\section{REPOSITORY RECORD}

Wilson, Samantha L., Ying Yang, and Alicia J. El Haj. 2019. "Restoration of Keratocyte Cell Phenotype Through Epithelial-stromal Cell Interactions in a 3D Hydrogel Model [abstract]". figshare. https://hdl.handle.net/2134/26839. 


\title{
Restoration Of Keratocyte Cell Phenotype Through Epithelial-Stromal Cell Interactions In A 3D Hydrogel Construct
}

\author{
S.L. Wilson*, Y. Yang, A.J. El Haj
}

Institute for Science and Technology in Medicine, School of Medicine, Keele University,

Stoke-on-Trent, ST4 7QB, UK

In vivo, epithelial cells are connected both anatomically and functionally with stromal keratocytes. Co-culturing aims to recapture this cellular anatomy and functionality by bringing together two or more cell types within the same culture environment.

Corneal stromal cells were activated to their injury phenotype (fibroblasts) before being encapsulated in 3D collagen hydrogels. 3 different epithelial-stromal co-culture methods were then examined; epithelial explant; transwell; the use of conditioned media. Using our non-destructive monitoring tools we revealed how epithelial co-culturing affects stromal cell differentiation in terms of construct contraction and elastic modulus measurements in a 3D collagen hydrogel environment for prolonged culture periods. Cell viability, phenotype, morphology and protein expression was investigated to corroborate our mechanical findings.

It was shown that activated stromal cells retain their plasticity in vitro. Activated corneal stromal cells that were fibroblastic in phenotype were successfully reverted to a nonactivated keratocyte cell lineage in terms of behaviour and biological properties; and then back again via TGF- $\beta 1$ media supplementation. It was then revealed that epithelial-stromal interactions can be blocked via the use of wortmannin inhibition. A greater understanding of stromal-epithelial interactions and what mediates them offers great pharmacological potential in the regulation of corneal wound healing, with the potential to treat corneal diseases and injury whereby such interactions are vital. 